Mycologia, 103(6), 2011, pp. 1372-1383. DOI: 10.3852/11-005

(C) 2011 by The Mycological Society of America, Lawrence, KS 66044-8897

\title{
A new species and new records of Cercophora from Argentina
}

\author{
Myriam del Valle Catania \\ Fundación Miguel Lillo, Laboratorio de Micología. \\ Miguel Lillo 251. San Miguel de Tucumán (4000), \\ Argentina \\ Andrea I. Romero ${ }^{1}$ \\ PRHIDEB-CONICET-Departamento de Biodiversidad y \\ Biología Experimental, Facultad de Ciencias Exactas y \\ Naturales, Universidad de Buenos Aires, Ciudad \\ Universitaria, Pabellón 2 4to piso (1428), Buenos \\ Aires, Argentina
}

Sabine M. Huhndorf Botany Department, The Field Museum, 1400 South Lake Shore Drive, Chicago, Illinois 60605

Andrew N. Miller

Illinois Natural History Survey, University of Illinois, 1816 South Oak Street, Champaign, Illinois 618206970

Abstract: Three species of Cercophora were found during a survey of the biodiversity of microfungi in northwest Argentina. Cercophora argentina possesses a unique combination of morphological characters and is described as a new species, while $C$. costaricensis and C. solaris are reported as new records for Argentina. Other species of Cercophora known from this region include $C$. natalita and $C$. coprogena, which is fully illustrated for the first time and determined herein to be a synonym of $C$. californica. All other species are described and illustrated.

Key words: Lasiosphaeriaceae, Podocarpus parlatorei, Sambucus nigra, Sordariales, systematics, Yungas

\section{INTRODUCTION}

Cercophora Fuckel is characterized morphologically by large, membranaceous to carbonaceous, ostiolate, papillate ascomata; asci with an apical ring usually with a subapical globule and ascospores with a brown, swollen head and a hyaline pedicel at maturity. Its most common anamorphs are found in the form genera Phialophora (Udagawa and Muroi 1979), Cladorrhinum (von Arx 1981) and Chrysosporium (Ueda 1994). Species in the genus can be coprophlilous (Lundqvist 1972), xylophilous (Hilber and Hilber 1979) or less frequently are found on soil or in aquatic habitats (Ueda 1994, Chaudhary et al. 2007). Cercophora presently comprises 67 taxa, ac-

Submitted 4 Jan 2011; accepted for publication 19 Apr 2011.

${ }^{1}$ Corresponding author. E-mail: romero@bg.fcen.uba.ar cording to Index Fungorum (www.indexfungorum. org, 7 Feb 2011).

Miller and Huhndorf (2005) showed that Cercophora and other sordariaceous genera are paraphyletic or polyphyletic and concluded that the peridium anatomy is a better indicator of phylogenetic relationships than ascospore morphology in some cases. With respect to the southern cone of South America only Cercophora sordarioides (Speg.) N. Lundq. on dung and Cercophora natalitia (Speg.) N. Lundq. on a dead trunk had been reported from Argentina, while Cercophora coprogena (Speg.) N. Lundq. on dung had been reported from Chile (Lundqvist 1972). Three species of Cercophora were found during our biodiversity studies on Argentinian microfungi occurring on bark and decorticated wood of a native gymnosperm, Podocarpus parlatorei Pilg. One of these possesses a unique combination of characters not known in any other species in the genus and thus is described as new. Two additional Cercophora species are reported and illustrated from Argentina for the first time, while type specimens of three other species known from this area are fully illustrated for the first time.

\section{MATERIALS AND METHODS}

Collections were made in a Podocarpus parlatorei forest and in a mixed forest from Cumbres de Taficillo, Sierra de San Javier, Departamento Tafí Viejo, Tucumán province, Argentina. The study area belongs to the District Mountain Forest of the phytogeographical region of Las Yungas, a subtropical zone of the Amazonic Domain, Neotropical Region, which encompasses the Andes from Venezuela and Colombia, entering the northwestern part of Argentina as a narrow section through Jujuy in the north to Salta, Tucuman and finally Catamarca provinces in the south (Cabrera and Willink 1973, Hueck 1978). Fallen stems of Podocarpus parlatorei Pilg. and Sambucus nigra L. ssp. peruviana (Kunth) R. Bolli containing ascomata were collected. The material was dried and deposited in the herbaria of Fundación Miguel Lillo (LIL) and the Illinois Natural History Survey (ILLS).

Observations, digital imaging and measurements of ascomata, asci and ascospores were made on material mounted in distilled water, $5 \% \mathrm{KOH}$ and phloxine with either an Olympus CX31 microscope and Olympus SP-350 digital camera or a Zeiss Axioskop microscope and a Dage MTI video camera. Material mounted in calcofluor (Romero and Minter 1988) was examined by epifluorescence (EF) microscopy with a Zeiss Axioplan to observe ascospores 
and apical rings in the asci. Drawings were made with a camera lucida.

Attempts were made to culture these species. Ascospores were removed from ascomata with a sterile needle and transferred to Petri plates containing potato dextrose agar (PDA) (Hawksworth et al. 1995). They were incubated under laboratory conditions with approximately $12 \mathrm{~h}$ fluorescent light per day at 25 C. No cultures were obtained due to lack of ascospore germination.

\section{RESULTS AND DISCUSSION}

Cercophora argentina Catania, A.I. Romero, Huhndorf \& A.N. Mill., sp. nov.

FIGS. 1-20

Ascomata perithecialia ovalia, 750-900 × 450-500 $\mu \mathrm{m}$, superficialia; collum cilindricum vel conicum, leviter curvatum, nigrum, glabrum. Peridium membranaceum, brunneum, tristratosum, cellulis cum poris Munki. Asci 8spori, annulo apicali haud profundo, simplici; globulus subapicalis absens. Ascosporae in statu hyalino unicellulares, cylindraceae, (58.5-)61-73 × (-4)5-6.5 $\mu \mathrm{m}$, leviter sigmoideales vel geniculatae cum appendicibus bipolaribus dein uniseptatae; cellula superior brunnea, clavata vel ellipsoidea, $18-22 \times 9.0-12 \mu \mathrm{m}$; pedicellus $0-3(-4)$ septatus, hyalinus ad brunneum, 35-50 × 4.5-5 $\mu \mathrm{m}$. Lignicola.

\section{MycoBank MB519727}

Etymology: Refers to the type country.

Ascomata perithecial ovoid, $750-900 \times 450-500 \mu \mathrm{m}$, numerous, in small groups or densely crowded, superficial; neck cylindrical to conical, slightly bent, dark brown to black, glabrous; subiculum sparse at the base, composed of branched, pale to dark brown hyphae, 3-5 $\mu \mathrm{m}$ diam, thick-walled, septate. Ascomatal wall of textura angularis in surface view, cells thickwalled, pale to dark brown, 9-16 $\mu \mathrm{m}$ diam, cells with numerous Munk pores; in longitudinal section threelayered, 90-200 $\mu \mathrm{m}$ wide; outer layer 11-13 $\mu \mathrm{m}$ thick, composed of thick-walled, irregular, brown cells, 5$9 \mu \mathrm{m}$ diam; middle layer $72-90 \mu \mathrm{m}$ thick, composed of thin-walled, isodiametric to rectangular, hyaline to pale brown cells, 12-14(-27) $\mu \mathrm{m}$ diam; inner layer 13$17 \mu \mathrm{m}$ thick, composed of elongate, thin-walled, brown cells, 13-26(-35) $\times$ 4-5 $\mu \mathrm{m}$. Asci cylindrical, part sporifera $150-240 \times 12-18 \mu \mathrm{m}$, long-stipitate, stipe 45-78(-96) $\mu \mathrm{m}$ long, unitunicate, ring narrow, shallow, refractive; subapical globule absent; with eight biseriate ascospores. Paraphyses hyaline, numerous, septate, 2-3 $\mu \mathrm{m}$ diam. Ascospores cylindrical, ends rounded, (58.5-)61-73 $\times(-4) 5-6.5 \mu \mathrm{m}$, slightly sigmoid or geniculate, hyaline, aseptate, with granulate content; with bipolar appendages, up to $55 \mu \mathrm{m}$ long, hyaline, appendages generally collapse and disappear with age; ascospore becoming differentiated into a swollen head and pedicel, transversely uniseptate; head clavate to elliptical, aseptate or with a transverse septum in the middle or slightly below the middle, 18$22 \times 9.0-12 \mu \mathrm{m}$, truncate at the base, hyaline, becoming pale yellow to dark brown; pedicel $35-50$ $\times 4.5-5 \mu \mathrm{m}, 0-3(4-)$ septate, hyaline to pale brown, with granulate content and numerous oil drops.

Anamorph: unknown.

Habitat: on fallen branch of Sambucus nigra ssp. peruviana (Kunth) Bolli. This species belongs to the family Caprifoliaceae and is a native shrub or tree in Argentina occurring at 1500-2000 s.l.m, in several provinces including northwestern Catamarca, Jujuy, southwestern Neuquén and Tucumán (Zuloaga and Morrone 1999).

Geographic distribution: Argentina (Tucumán).

Material examined: ARGENTINA. TUCUMÁN: Dpto. Tafí del Valle, La Heladera, 1300 s.l.m, $27^{\circ} 01^{\prime} 20^{\prime \prime}$ S, $65^{\circ} 39^{\prime} 10^{\prime \prime} \mathrm{W}$, 20-IV-2006, Hladki 2945, on stem of Sambucus nigra L.ssp. peruviana (HOLOTYPE LIL; ISOTYPE ILLS 60485).

Cercophora argentina occurs on wood and possesses a non-areolate peridium with Munk pores and ascospores, $61-73 \times 5-6.5 \mu \mathrm{m}$. Cercophora appalachianensis O. Hilber \& R. Hilber and C. californica are two other species of Cercophora that are reported to have Munk pores in the peridial cells. However both are different from C. argentina. Cercophora appalachianensis possesses ascomata covered by long hairs, smaller ascospores, 37-48(-68) $\times 3.5-4.5 \mu \mathrm{m}$, and shorter ascospore appendages (Hilber et al. 1987), while C. californica, on dung, possesses an areolate ascomatal wall and longer ascospores $(75.5-95 \mu \mathrm{m})$, although the original description incorrectly describes the ascospores as being 30-35 $\mu \mathrm{m}$ long (Plowright 1878). Molecular studies have shown that many genera in the Sordariales, including Cercophora, are polyphyletic (Miller and Huhndorf 2005). This new species is proposed within the genus based on morphological characters.

Cercophora californica (Plowr.) N. Lundq., Symb. Bot. Upsal. 20:106, 1972.

$\equiv$ Sordaria californica Plowr., Grevillea 7:72, 1878.

$=$ Cercophora coprogena (Speg.) N. Lundq., Symb. bot. upsal. 20:105, 1972.

$\equiv$ Podospora coprogena Speg., Bol. Acad. Nac. Ci. (Córdoba) 25:50, 1921.

FIGS. 21-40

Ascomata ovoid to obpyriform, dark brown, firm consistency (cartilaginous), papillate, 600-900 $\mu \mathrm{m}$ diam, 850$1000 \mu \mathrm{m}$ tall, numerous, clustered in large groups, immersed becoming erumpent; surface roughened; neck conical, deeply 7-8-sulcate, distinct; subiculum absent. Ascomatal wall weakly areolate in surface view; $60-70 \mu \mathrm{m}$ thick in longitudinal section, two-layered, composed of thick-walled scleroplectenchymatous to pseudoparenchymatous cells, with an inner, hyaline layer with numerous Munk pores and an outer, unevenly brown pigmented layer. Ascomatal apex without apparent periphyses. Paraphyses 

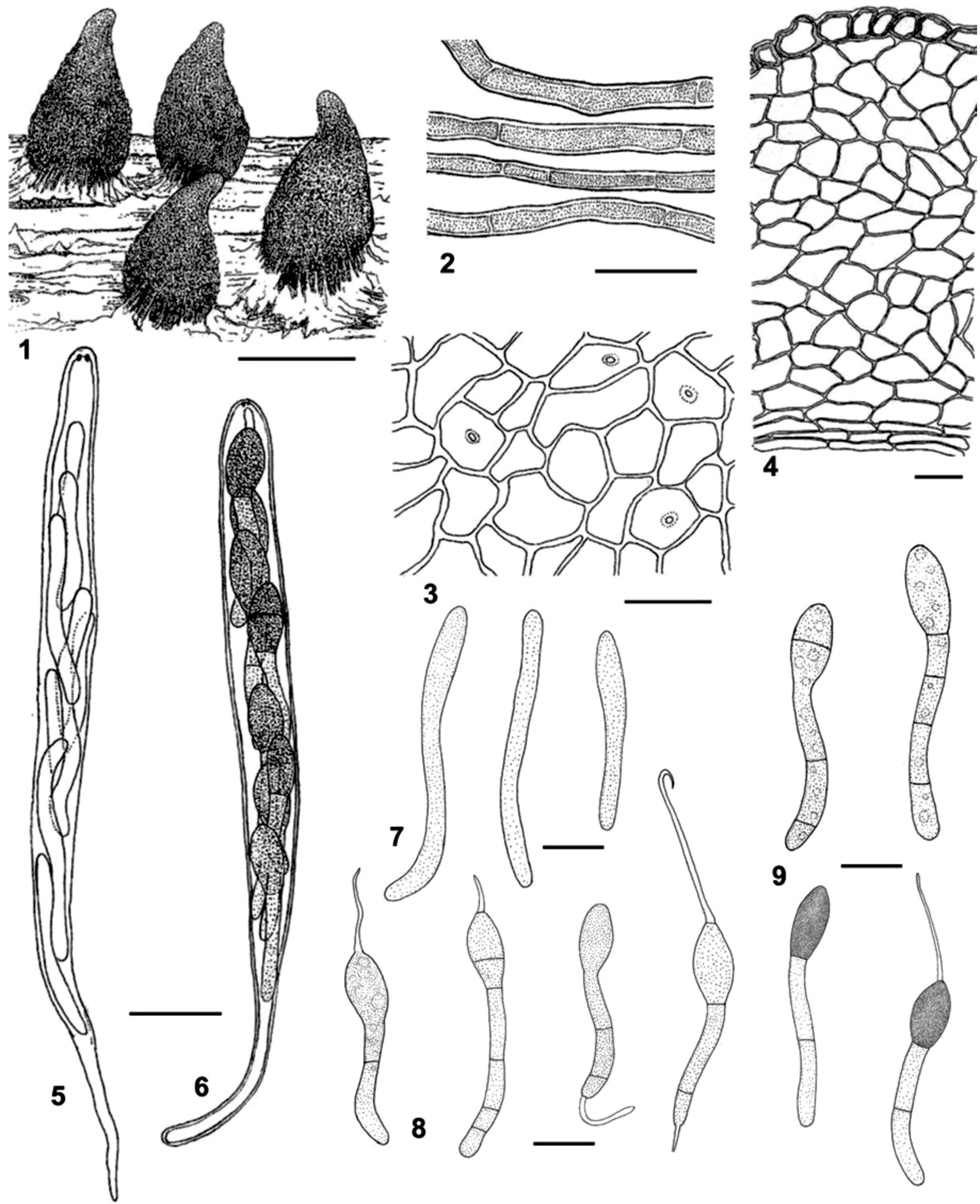

FIGS. 1-9. Cercophora argentina sp. nov. (Holotype LIL Hladki 2945). 1. Ascomata on substrate. 2. Subiculum hairs. 3. Surface view of ascomal wall, cells with Munk pores. 4. Longitudinal section through ascomal wall. 5. Ascus with young ascospores. 6. Ascus with mature ascospores. 7. Young ascospores. 8. Ascospores with appendages. 9. Mature ascospores. Bars: 1 $=0.5 \mathrm{~mm}, 2-9=10 \mu \mathrm{m}$. 


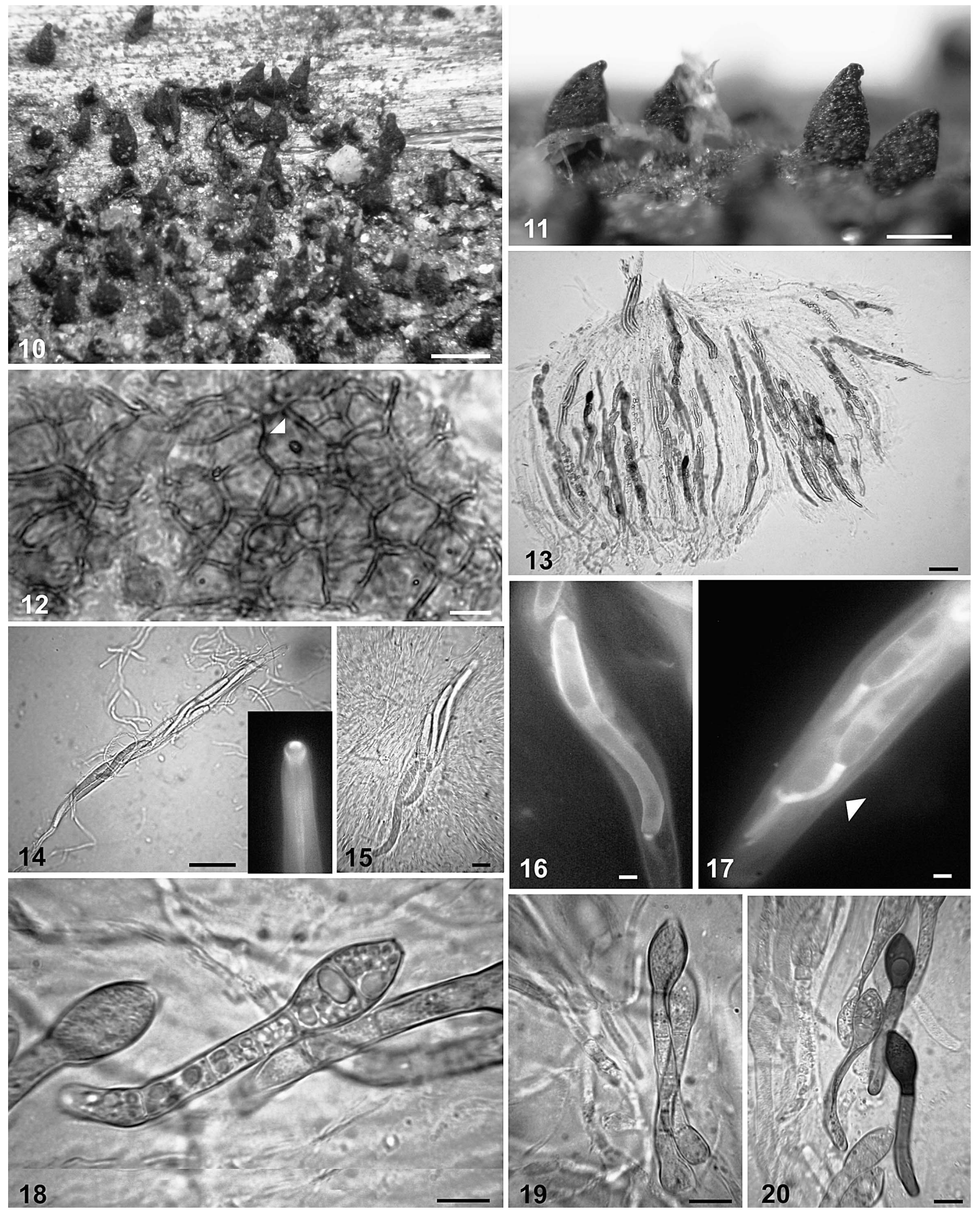

Figs. 10-20. Cercophora argentina sp. nov. (Holotype LIL Hladki 2945). 10-11. Ascomata on substrate. 12. Surface view of ascomal wall, cells with Munk pores. 13. Asci and paraphyses. 14. Ascus, plus detail of apex with EF (inset). 15. Ascus. 16-17. Ascospore with appendage (arrow) (EF). 18-19. Ascospores in different stages of development. 20. Mature ascospore. Bars: 10 $=1 \mathrm{~mm} ; 11=0.5 \mathrm{~mm} ; 12,16-17=5 \mu \mathrm{m} ; 13-14=25 \mu \mathrm{m} ; 15,18-20=10 \mu \mathrm{m}$. 


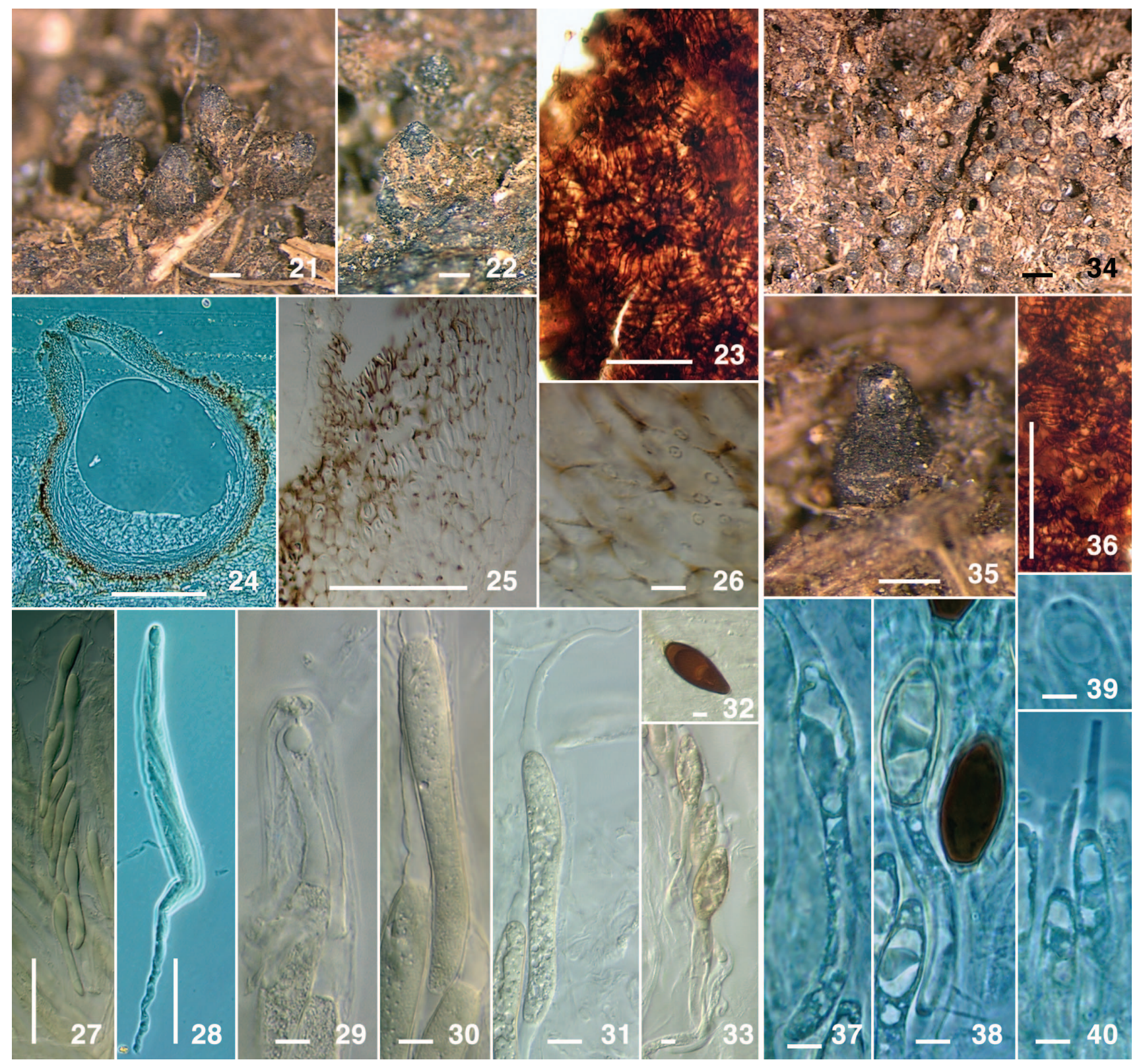

Figs. 21-33. Cercophora californica (Holotype KM68745; Isotype NY). 21, 22. Ascomata on substrate. 23. Surface view of ascomal wall. 24. Longitudinal section through ascoma. 25, 26. Longitudinal section through ascomatal wall with Munk pores. 27, 28. Asci. 29. Ascus apex. 30-33. Ascospores. 21, 24, 25. From Holotype; 22, 23, 26-33. From Isotype. 34-40. Cercophora coprogena (Holotype LPS 6856). 34, 35. Ascomata on substrate. 36. Surface view of ascomal wall. 37, 38. Ascospores. 39. Ascus apex. 40. Ascospore appendages. Bars: $34=1 \mathrm{~mm}$; 21, 22, 24, $35=0.5 \mathrm{~mm}$; 23, 25, 27, 28, $36=100 \mu \mathrm{m}$; 26, 29-33, 37-40= $10 \mu \mathrm{m}$.

filiform, 3-4 $\mu \mathrm{m}$ wide, abundant, septate, unbranched, persistent. Asci cylindrical, spore-bearing part 250-350 $\times$ 20-30 $\mu \mathrm{m}$, numerous, unitunicate, thin-walled, apex blunt; ring narrow, shallow; subapical globule present; with eight biseriate ascospores. Ascospores cylindrical, ends rounded, slightly sigmoid, hyaline, aseptate; becoming differentiated into a swollen head and pedicel and transversely uniseptate; $70-90(-95) \times 6-10 \mu \mathrm{m}$, head ellipsoid, 30-35 × 14-16 $\mu \mathrm{m}$, conical at the apex, truncate at the base, hyaline to dark brown; bipolar appendages present, 20-40(-80) $\mu \mathrm{m}$, gelatinous, lash-like.

Material examined: CHILE. Los Perales, 1918, on cow dung, C. Spegazzini 6856 (HOLOTYPE of P. coprogena, LPS). USA. CALIFORNIA, on cow dung, H.W. Harkness $513(\mathrm{~K}(\mathrm{M}): 68745$, HOLOTYPE of $S$. californica, K; ISOTYPE, NY).

Cercophora californica appears to be the same as $C$. coprogena, which is a younger name and therefore a 
synonym. Both species occur on cow dung with $C$. californica known only from the type collection from California, USA, and C. coprogena known only from the type collection from Chile. In both species the ascomata are large and obpyriform with a distinctly sulcate neck (FIGS. 21, 35). The neck appears erumpent through a crusty surface on the dung with the entire ascomata eventually becoming erumpent (Figs. 22, 34). In both species the ascomatal wall in surface view is weakly areolate (FIGs. 23, 36). The cells are arranged in a circular pattern around a central darkened area but are not sufficiently distinct to crack into plates along the lines of the thin-walled hyaline cells. Also present is an uneven brown pigmentation in the outer wall cells of both species. Areolate peridia are seen in a number of Cercophora species that do not appear to be closely related based on analyses of DNA sequence data. The most distinct areolate pattern is seen in Cercophora areolata N. Lundq. where the walls are more strongly carbonized and distinct plates are formed that crack along the lines of weakness of the hyaline cells. Less carbonized but still distinct areoles are seen in C. solaris (Cooke \& Ellis) R. Hilber \& O. Hilber and C. striata (Ellis \& Everh.) N. Lundq. The indistinct or weak areolate type of walls seen in C. californica also is seen in $C$. coprophila (Fr.) N. Lundq. Areolate walls are not unique to the Sordariales; they also are found in widely distant taxa, such as Cephalotheca Fuckel (Cephalothecaceae) and Bertiella macrospora (Sacc.) Sacc. \& Traverso (Melanommataceae). The inner layer of the ascomal wall in C. californica has numerous Munk pores (FIG. 26) as seen in the new species, C. argentina, and as illustrated in $C$. appalachianensis. Munk pores are predominant in species in the Coronophorales (Nannfeldt 1975) but occasionally are seen in species outside this group (Huhndorf et al. 2004). They do not appear to be phylogenetically significant at taxonomic rank beyond species. The wall of C. californica also is composed of thick-walled cells (FIG. 25), similar to those seen in C. albicollis N. Lundq. The wall of $C$. albicollis has been interpreted as pseudo-bombardioid (Miller 2003) putatively similar to the walls found in C. costaricensis, C. elephantina (Henn.) N. Lundq. and C. scortea (Cain) N. Lundq., but these walls are not all the same. Cercophora albicollis and $C$. californica lack the gelatinized layer with ramifying hyphae found in the others. Only thick-walled cells are present and these are predominent in the neck region (FIG. 25). These two species probably represent another group of taxa with a distinct wall type, C. californica, differing with a weak areolate surface pattern not seen in C. albicollis.
Cercophora costaricensis (G.C. Carroll \& Munk) O. Hilber \& R. Hilber, Z. Mykol. 45:217, 1979.

$\equiv$ Bombardia costaricensis G.C. Carroll \& Munk, Mycologia $56: 80,1964 . \quad$ Figs. 41-48, 70-76

Ascomata perithecial ovoid, papillate, (350-) 400-500 $\mu \mathrm{m}$ high, 300-400 $\mu \mathrm{m}$ diam, numerous, gregarious, occasionally separated, superficial; surface rugose or granulate; neck conical, black, glabrous; subiculum sparse at the base, composed of brown hyphae, 3-4.5 $\mu \mathrm{m}$ diam, thick-walled, septate. Ascomatal wall of textura angularis in surface view, cells thick-walled, radially arranged around a darker center; in longitudinal section three-layered, 90-123.5 $\mu \mathrm{m}$ wide; outer layer 10-19(-25) $\mu \mathrm{m}$ thick, composed of thick-walled, dark brown cells, 5-8 $\mu \mathrm{m}$ diam; middle layer 52-81 (-84.5) $\mu \mathrm{m}$ thick, composed of thick-walled, gelatinized, hyphae, lumen ca. 1.5-2 $\mu \mathrm{m}$; inner layer 13-15(-17) $\mu \mathrm{m}$ thick, composed of elongate, hyaline to pale brown cells, $9-15 \times$ 1-2 $\mu \mathrm{m}$. Asci cylindrical, 135-186 × 13-16 $\mu \mathrm{m}$, longstipitate, stipe 30-66 $\mu \mathrm{m}$ long, numerous, unitunicate, thin-walled, apex truncate; ring narrow, shallow, refractive; subapical globule absent; with eight biseriate ascospores. Paraphyses not seen. Ascospores cylindrical, ends rounded, $40-49 \times 4-5 \mu \mathrm{m}$, slightly sigmoid or geniculate, hyaline, aseptate, plasmatic content granulate; with bipolar appendages, up to $20 \mu \mathrm{m}$ long, becoming differentiated into a swollen head and pedicel, transversely uniseptate; head elliptical, ovoid, aseptate, $18-22 \times 8-9(-10) \mu \mathrm{m}$, subacute to rounded at the apex, truncate at the base, hyaline to dark brown, with one or two oil drops; pedicel 22-27 $\times 4-5 \mu \mathrm{m}$, hyaline; appendages disappear with age.

Anamorph: unknown.

Habitat: on wood of fallen branch.

Geographic distribution: Argentina (Tucumán), Costa Rica (Hilber and Hilber 1979), Venezuela (Portuguesa).

Material examined: ARGENTINA: TUCUMÁN: Depto. Tafi Viejo, Parque Biológico Sierra de San Javier, Cumbres de Taficillo, Las Mentas, in forests of Podocarpus parlatorei, 1600 s.l.m, $26^{\circ} 42^{\prime} 820^{\prime \prime} \mathrm{S}, 65^{\circ} 19^{\prime} 530^{\prime \prime} \mathrm{O}, 24-\mathrm{V}-1999$, Catania 1669 (LIL, ILLS 60486). VENEZUELA: PORTUGUESA: road between La Estacion and Santa Rosa del Guache, approx 3 mi S Santa Rosa, 16-I-1993, S.M. Huhndorf, et al., $368(\mathrm{~F})$.

Our material agrees with the description by Hilber and Hilber (1979), except for the smaller size of the ascospore appendages (material studied by Hilber and Hilber were $35 \mu \mathrm{m}$ long, while material by Carroll and Munk [1964] were up to 100-200 $\mu \mathrm{m}$ long). However, as pointed out by Lundqvist (1972), measurements of these structures can vary greatly, depending on the amount of pressure placed on the cover slip at the time of slide preparation. The most striking feature of this species is the ascomal peridium, which was termed pseudo-bombardioid by Lundqvist (1972) and Miller (2003) because the ascomal wall is non-stromatic. The pseudo-bombardioid wall has been described in nine species in three genera of Lasiosphaeriaceae, Arnium ontariense (Cain) 



42
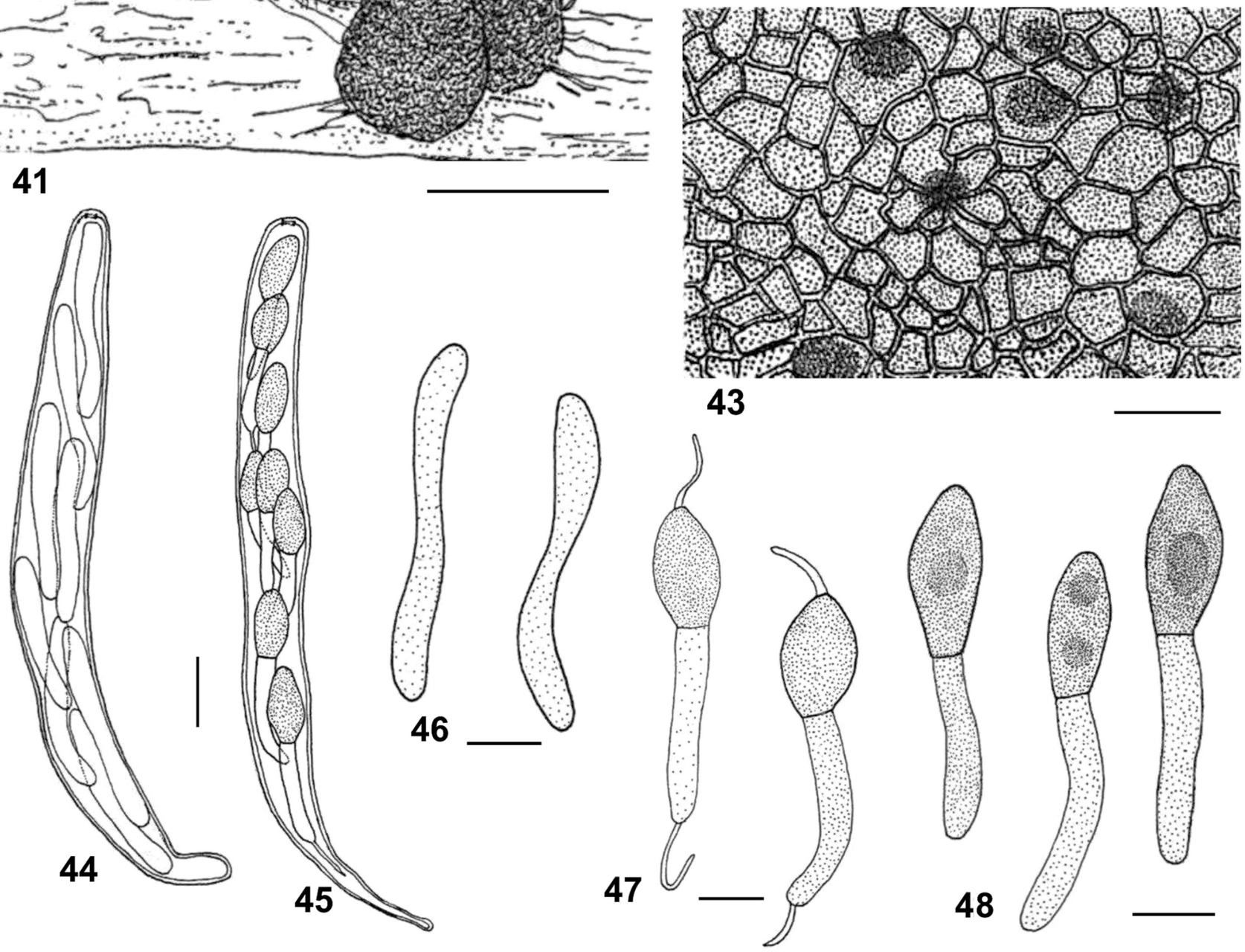

Figs. 41-48. Cercophora costaricensis (LIL Catania 1669). 41. Ascomata on substrate. 42. Subiculum hairs. 43. Surface view of ascomal wall. 44. Ascus with young ascospores. 45. Ascus with mature ascospores. 46. Young ascospores. 47. Ascospores with appendages. 48. Mature ascospores. Bars: $41=0.5 \mathrm{~mm} ; 42-48=10 \mu \mathrm{m}$.

J.C. Krug \& Cain; Cercophora albicollis, C. costaricensis, C. elephantina, C. palmicola Hanlin \& Tortolero, C. scortea, Podospora appendiculata (Auersw. ex Niessl) Niessl, P. fimiseda (Ces. \& de Not.) Niessl, and $P$. perplexans (Cain) Cain (Carroll and Munk 1964, Furuya and Udagawa 1972, Lundqvist 1972, Hilber and Hilber 1979, Hanlin and Tortolero 1987, Bell and Mahoney 1997).

The morphology of the pseudo-bombardioid wall is slightly homoplasious in the Sordariales and it appears to have arisen independently in two distantly related groups, although relationships among these 
groups were unsupported at that time according to Miller and Huhndorf (2005). They also pointed out that "while ascospore morphology cannot be used for delimiting genera, ascomal wall morphology alone or in combination with other characters is still useful at some level for distinguishing taxa".

Cercophora natalitia (Speg.) N. Lundq., Symb. Bot. Upsal. 20:94, 1972.

$\equiv$ Hypocopra natalitia Speg., An. Soc. Cient. Argent. 10:14, 1880.

Figs. 49-60

Ascomata obpyriform, dark brown, erumpent with only the papillate ostioles visible, scattered, membranaceous, 250-300 $\mu \mathrm{m}$ diam, 310-350 $\mu \mathrm{m}$ high, numerous, covered with flexuous, branched, septate, golden brown, 2-2.5 $\mu \mathrm{m}$ thick hairs; neck short, stout, darker brown than the rest of the peridium. Ascomatal wall of textura angularis in surface view; in longitudinal section two-layered, 20-40 $\mu \mathrm{m}$ thick, composed of pseudoparenchymatous cells, $3-5 \times 7-10 \mu \mathrm{m}$. Paraphyses filiform, abundant, septate, unbranched, persistent. Asci cylindrical, not possible to measure, numerous, unitunicate, thin-walled, apex blunt; ring not seen, subapical globule present; with eight biseriate ascospores. Ascospores becoming differentiated into a swollen head and pedicel, head 15-19 $\times 8-10 \mu \mathrm{m}$, conical at the apex, truncate at the base, pedicel hyaline, 4-6 $\times 30-40 \mu \mathrm{m}$, with a single appendage observed, although possibly bipolar, gelatinous, lash-like.

Material examined: ARGENTINA. BUENOS AIRES (FEDERAL CAPITAL), Recoleta, 20-IV-1880, on trunk of Pircunia dioica (L.) Moq. (= Phytolacca dioica L.), C. Spegazzini (HOLOTYPE LPS 6841).

Lundqvist (1972) said "Cercophora natalitia is very close to the lignicolous Cercophora caudata (Curr.) N. Lundq., which differs by its short caudae and more pronounced swollen cells and hairs on the neck" (according to annotation label when Lundqvist examined Spegazzini's collection). He also pointed out (1972: 94) "this species differs mainly by up to $55 \mu \mathrm{m}$ long gelatinous caudae and a simple, narrower $(3 \mu \mathrm{m})$ apical ring". Cercophora aquatica $\mathrm{P}$. Chaudhary, J. Fourn. \& A.N. Mill. (Chaudhary et al. 2007) is similar to C. natalitia in that both share aquatic habitats, but the former can be distinguished by its areolate ascomatal wall, lack of a subapical globule and double ascus apical ring. Cercophora natalitia is distinguished from C. argentina by its mostly immersed ascomata with ascomatal hairs and a short, stout neck, and the presence of a subapical globule.

The habitat in the locality where Spegazzini found C. natalitia does not exist anymore. Today the locality is a tourist neighborhood in the middle of Buenos Aires. To look for this species today, one might search along the marginal forest on the Río de La Plata north or south of the city.
Cercophora solaris (Cooke \& Ellis) R. Hilber \& O. Hilber, Z. Mykol. 45:221, 1979.

$\equiv$ Sphaeria solaris Cooke \& Ellis, Grevillea 5:1876.

$\equiv$ Lasiosphaeria solaris (Cooke \& Ellis) Sacc., Syll. Fung. 2:2002, 1883.

$\equiv$ Thaxteria solaris (Cooke \& Ellis) Höhn, Ann. Mycol. 16:75, 1918. FIGS. 61-69, 77-85

Ascomata globose to subglobose, papillate, (300-)400$500 \mu \mathrm{m}$ high, 300-450 $\mu \mathrm{m}$ diam, numerous, gregarious, superficial; surface rugose, short; neck sulcate or glabrous, black; subiculum sparse at the base, composed of branched, brown hyphae, 3-4,5 $\mu \mathrm{m}$ diam. Ascomatal wall areolate in surface view, irregular, carbonaceous, composed of dark brown to black, erect thin-walled, rectangular cells radially arranged around dark brown cells, up to $21 \mu \mathrm{m}$ diam; in longitudinal section three-layered, 30$80 \mu \mathrm{m}$ wide; outer layer $4-12.5 \mu \mathrm{m}$ thick, composed of brown cells; middle layer 14-22 $\mu \mathrm{m}$ thick, composed of irregular, dark brown to black cells; inner layer 6.5-18.5 $\mu \mathrm{m}$ thick, composed of elongate, thin-walled slightly colored cells. Asci cylindrical, 110-127.5 × (-9) 10-12 $\mu \mathrm{m}$, unitunicate, thin-walled, apex truncate; ring narrow, shallow, refractive; subapical globule absent; with 8 biseriate ascospores. Paraphyses hyaline, numerous, septate, branched. Ascospores cylindrical, ends rounded, 19-25 $\times$ 4-4.5 $\mu \mathrm{m}$, slightly sigmoid or geniculate, hyaline, aseptate, sometime with 1-2-septate, without bipolar appendages, germination by germ tubes; becoming differentiated into a swollen head and pedicel, transversely uniseptate; head elliptical, truncate at the base, aseptate, 10-12(-13) $\times 5$ $6.5 \mu \mathrm{m}$, dark brown; pedicel $8-10(-12) \times 3-4 \mu \mathrm{m}$, hyaline, collapsing.

Anamoph: Mammaria echinobotryoides Cesati, and a phialophora-like synanamorph, were obtained in culture by Samuels (pers comm in Barr 1990), from ascospores of Cercophora solaris.

Habitat: on bark and wood of fallen branch.

Material examined: ARGENTINA. TUCUMÁN: Depto. Tafí Viejo, Parque Biológico Sierra de San Javier, Cumbres de Taficillo, Las Mentas, in forests of Podocarpus parlatorei, 1600 s.l.m; $26^{\circ} 42^{\prime} 820^{\prime \prime}$ S, $65^{\circ} 19^{\prime} 530^{\prime \prime} \mathrm{W}, 1-\mathrm{III}-1999$, Catania 1326 (LIL); ibid., 24-V-1999, Catania 1664 (LIL, ILLS 60487).

Geographic distribution: Argentina (Tucumán); Germany, USA (Hilber and Hilber 1979); New Zealand (Pennycook and Galloway 2004) and Taiwan (Hsieh et al. 2000).

Our material agrees with the description by Hilber and Hilber (1979). This species possesses a weakly areolate wall, as in C. californica, but is easily distinguished by its short, comma-shaped ascospores. Only one other species of Cercophora, C. spinosa (Harkn.) M.E. Barr, possesses similarly shaped ascospores, but this species can be separated by its thickwalled setae on the ascomata and its shorter ascospores (11-12 vs. 19-25 $\mu \mathrm{m}$ ) (Barr 1993). Although not commonly collected, C. solaris appears to have a wide geographical distribution because ITS 



Figs. 49-60. Cercophora natalitia (Holotype LPS 6841). 49. Macroscopic view of the type. 50. Spegazzini's drawing on the front of the envelope. 51. Ascoma. 52-53. Ascomata immersed in the substratum and covered by sediments. 54, 56. Longitudinal section of an ascoma. 55. Ostiole surrounded by darker cells, with ascospore being released. 57. Surface view of the peridium with hairs. 58. Young ascus; note the subapical globule (arrow) and a gelatinous cauda (arrow). 59, 60. Ascospores. Bars: $49=1.5 \mathrm{~cm}$; $51=150 \mu \mathrm{m} ; 52=1 \mathrm{~mm} ; 53=0.2 \mathrm{~mm} ; 54=50 \mu \mathrm{m} ; 55,56=20 \mu \mathrm{m} ; 57=25 \mu \mathrm{m} ; 58-60=10 \mu \mathrm{m}$. 



63
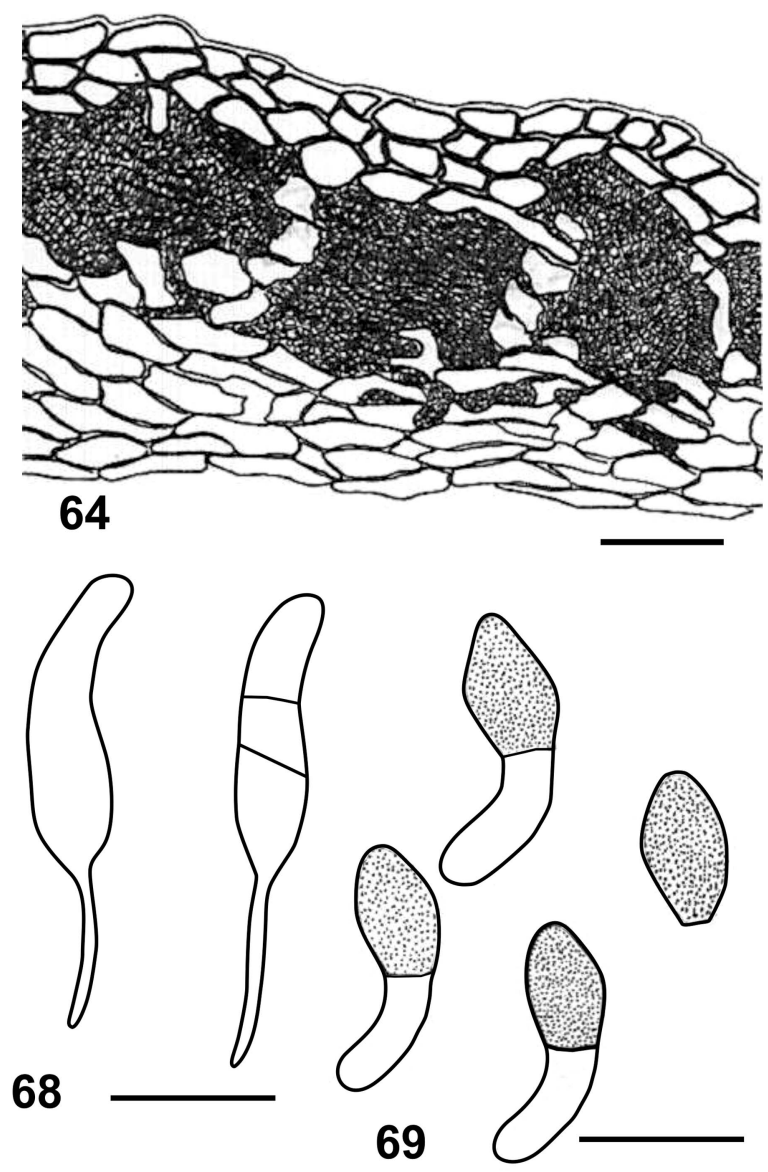

FIGS. 61-69. Cercophora solaris (LIL Catania 1326). 61. Ascomata on substrate. 62. Subiculum hairs. 63. Surface view of ascomal wall. 64. Longitudinal section through ascomal wall. 65. Ascus with young ascospores. 66. Ascus with mature ascospores. 67. Young ascospores. 68. Ascospores with germ tube. 69. Mature ascospores. Bars: $61=0.5 \mathrm{~mm}, 62-69=10 \mu \mathrm{m}$. 

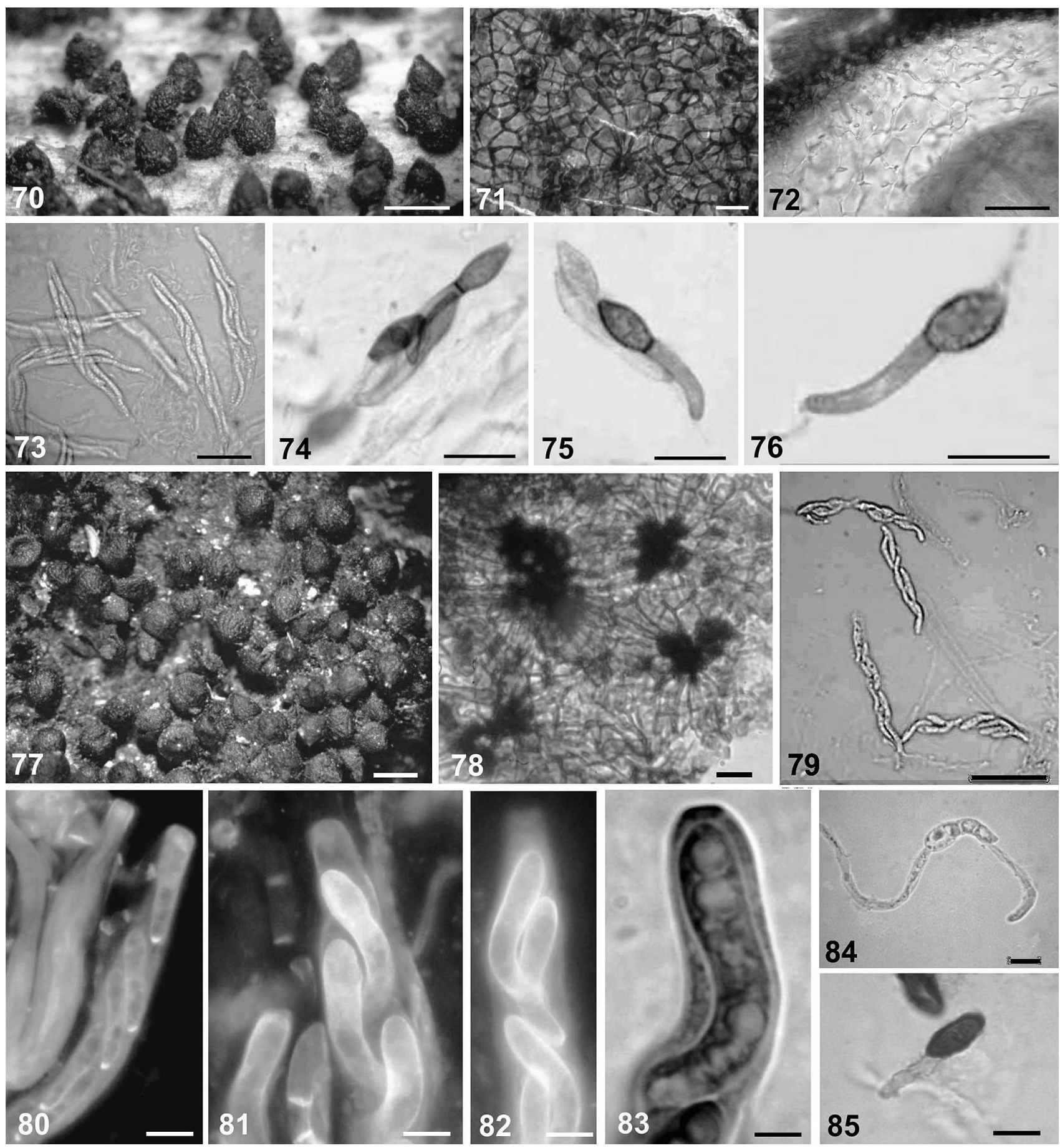

FIGs. 70-76. Cercophora costaricensis (LIL Catania 1669). 70. Ascomata on substrate. 71. Surface view of ascomatal wall. 72. Cross section through ascomatal wall. 73. Asci. 74, 75. Ascospores. 76. Mature ascospore with appendages. 77-85. Cercophora solaris (LIL Catania 1326). 77. Ascomata on substrate. 78. Surface view of outer areolate ascomatal wall. 79. Asci. 80-82. Asci and ascospores (EF). 83. Ascus, detail of apex. 84. Ascospores with germ tube. 85. Mature ascospore. Bars: $70,77=0.5 \mathrm{~mm} ; 71$ $=15 \mu \mathrm{m} ; 72-73=50 \mu \mathrm{m} ; 74-76=20 \mu \mathrm{m} ; 78,79,80-82,84,85=10 \mu \mathrm{m} ; 83=5 \mu \mathrm{m}$.

and LSU sequences generated from specimens from New Zealand and USA differ by only a few base pairs (Miller pers data). Multiple attempts to sequence Argentinian material (Catania 1664) of C. solaris failed (Miller pers comm). Previous hosts given for this species were angiosperms (Acer sp. and Populus sp.), thus this is the first time $C$. solaris is reported on a gymnosperm. 


\section{ACKNOWLEDGMENTS}

We thank the directors of herbaria LIL and LPS for kindly providing material for investigation. We express our appreciation to the authorities of Fundación Miguel Lillo, Tucumán, for financial support. We also are grateful for the help of Inés Jaume for the ink drawings, and Lic. Francisco Kuhar for the Latin assistance.

This is publication $\mathrm{N}^{\circ} 183$ of the PRHIDEB-PROPLAME, partially financed by the Argentine National Research Council.

\section{LITERATURE CITED}

Barr ME. 1990. Prodromus to nonlichenized, pyrenomycetous members of class Hymenoascomycetes. Mycotaxon 39:43-184.

- 1993. Redisposition of some taxa described by J.B. Ellis. Mycotaxon 46:45-76.

Bell A, Mahoney DP. 1997. Coprophilous fungi in New Zealand II. Podospora species with coriaceous perithecia. Mycologia 89:908-915, doi:10.2307/3761111

Cabrera AL, Willink A. 1973. Biogeografía de América Latina. Monografía 13. Washington, DC: Serie de Biología. Secretaria Gral. de la OEA. 122 p.

Carroll GC, Munk A. 1964. Studies on lignicolous Sordariaceae. Mycologia 56:77-98, doi:10.2307/3756400

Chaudhary P, Fournier J, Miller AN. 2007. Cercophora aquatica sp. nov. from a streambed in southern France. Sydowia 59:217-225.

Furuya K, Udagawa SI. 1972. Coprophilous pyrenomycetes from Japan I. J Gen Appl Microbiol 18:433-454.

Hanlin RT, Tortolero O. 1987. A new species and a new combination in Cercophora. Mycotaxon 30:407-416.

Hawksworth DL, Kirk PM, Sutton BC, Pegler DN. 1995. Ainsworth \& Bisby's Dictionary of the Fungi. 8th ed. Wallingford, UK: CAB International. $616 \mathrm{p}$.

Hilber O, Hilber R, Miller OK Jr. 1987. Fungi of the Appalachian Mountains. Mycotaxon 30:269-288.

Hilber R, Hilber O. 1979. Einige Anmerkungen zu der Gattung Cercophora Fuckel (Lasiophaeriaceae). Z Mykol 45:209-233.
Hsieh WH, Chen CY, Wang CL. 2000. Taiwan Ascomycetes-Pyrenomycetes and Loculoascomycetes. Taichung, Taiwan: China Graphics. 244 p. (In Chinese)

Hueck K. 1978. Los bosques de Sudamérica. Eschborn, Alemania: Sociedad Alemana de Cooperación Técnica. $476 \mathrm{p}$.

Huhndorf SM, Miller AN, Fernández FA. 2004. Molecular systematics of the Coronophorales and new species of Bertia, Lasiobertia and Nitschkia. Mycol Res 108:13841398, doi:10.1017/S0953756204001273

Lundqvist N. 1972. Nordic Sordariaceae s. lat. Symb Bot Uppsala 20:1-374.

Miller AN. 2003. A reinterpretation of the pseudo-bombardioid ascomal wall in taxa in the Lasiophaeriaceae. Sydowia 55:267-273.

- Huhndorf SM. 2005. Multigene phylogenies indicate ascomal wall morphology is a better predictor of phylogenetic relationships than ascospore morphology in the Sordariales (Ascomycota). Mol Phylogenet Evol 35:60-75, doi:10.1016/j.ympev.2005.01.007

Nannfeldt JA. 1975. Stray studies in the Coronophorales (Pyrenomycetes) 4-8. Svensk Bot Tidskrift 69:289-335.

Pennycook SR, Galloway DJ. 2004. Checklist of New Zealand "fungi', Fungi of New Zealand. Nga Harore o Aotearoa 1:401-488. Hong Kong: Fungal Diversity Press.

Plowright CB. 1878. California Sphaeriae. Grevillea 7: 71-74.

Romero AI, Minter DW. 1988. Fluorescente microscopy: an aid to the elucidation of ascomycete structures. Trans Br Mycol Soc 90:457-470, doi:10.1016/S0007-1536(88)80156-6

Udagawa S, Muroi T. 1979. Copropilous Pyrenomycetes from Japan V. Trans Mycol Soc Japan 20:453-468.

Ueda S. 1994. A new Cercophora with a Chrysosporium-like anamorph. Mycoscience 35:287-290, doi:10.1007/ BF02268451

von Arx JA. 1981. On Monila sitophila and some families of Ascomycetes. Sydowia 34:13-29.

Zuloaga FO, Morrone O. 1999. Catálogo de las Plantas Vasculares de la República Argentina II. AcanthaceaeEuphorbiaceae (Dicotyledoneae). St Louis: Missouri Botanical Garden Press. 1269 p. 